\title{
THE NOBLEWOMAN'S COURT IN THE SIXTEENTH-CENTURY GRAND DUCHY OF LITHUANIA
}

\author{
Raimonda Ragauskiene
}

\begin{abstract}
Drawing on an extant list of courtiers (1552) of the wife of the starosta of Žemaitija, references in correspondence, posthumous property inventories and individual pieces of legislation, the present article aims to illustrate the generalized composition of sixteenth-century noblewomen's court in the GDL, and the functions of those attached to such courts. At the same time an attempt is made to determine the role of noblewomen in appointing officials and co-opting court members and, in general, establishing the limits of their rights and patronage.

The size of the court depended on the social position of the lady as its head - on the office held by her husband and on the role of the noblewoman herself in her family as well as on her personality. Minors were attended merely by a few servants, while the courts of married women and in particular those of widows comprised between 50 and 60 courtiers. As a rule, noblewomen's courts consisted of several parts that functioned as a single unit: court officials, the male quarters (male courtiers and messengers), court specialists (medical practitioners, clergymen and musicians), the female quarters (ladies, young ladies and lady's maids) and court staff (servants, craftsmen and coachmen). The role of the husband was crucial in the formation of noblewomen's court. Noblewomen themselves could transform their court after the death of their husbands.
\end{abstract}

The maintenance of a large number of court members required massive investment on the part of noblewomen. Nevertheless, such investment, albeit without any obvious dividends, paid off ultimately. The court was a matter of their prestige; it was important in raising noblewomen's status in society. A court enabled them to develop their clientele and to participate actively in public life and create their own home clientele. Through their mediation their clients could become clients of their husbands or of their friends of the same high social status.

A rigid division of interests and spheres of activity was typical of Lithuanian society in the sixteenth century: the traditional place of women was the family in its widest sense, while social and political positions were male preserves. On the other hand, despite various signs (e.g. the practice of adopting their husbands' name), attesting 
the common rule that vir est caput mulieris, noblewomen did not consider themselves an injured party in the Grand Duchy of Lithuania in the sixteenth century. At least the extant sources do not show any signs of their aversion to discrimination; they considered the contemporary order just, acceptable and not beneath their dignity. That was mainly due to the absence of the perception that there could be ways of changing the status quo and living differently. Nevertheless, it is noteworthy that historians, who judge from a modern perspective, are inclined to accentuate and exaggerate the patriarchal nature of sixteenth-century society and the weakness of the position of the female therein. As a matter of fact, noblewomen managed to find ways not only to participate in the public life, but also to influence it actively. True, their real power is difficult to assess more precisely, as it was often veiled behind the authorities' institutions. Like in France in those days, noblewomen could exert their influence through patron-client relations. They appointed household clientele, controlled minor estate officials, had their own servants, acted as intermediaries at the royal court and regulated matrimonial matters. Enjoying financial support and the benefit of the ladies' intercession with husbands and other nobles, the noblewomen's clientele could turn into a political, religious and cultural force. In this way noblewomen themselves could acquire a chance to influence political events. ${ }^{1}$ The dictum that the world is ruled by men and men are ruled by women could have spread at that time.

However, it was only on their own estates that noblewomen could display their power and influence overtly and demonstrate their activity in public. ${ }^{2}$ Their authority was usually revealed through control of officials, their selection and dismissal of courtiers, how they created conditions for their careers or those of their families and, consequently, as they rallied the local gentry. Even poorly paid, courtiers thus guaranteed themselves lodging, board and clothing, and received occasional gifts; they could earn some extra money and put in a word in favour of their kin. Opportunities to become courtiers were ample.

${ }^{1}$ S. Kettering, 'The Patronage Power of Early Modern French Women', Historical Journal, vol. 32, 1989, pp. 817-841; eadem, 'Patronage and Kinship in Early Modern France', French Historical Studies, vol. 16, 1989, p. 422; eadem, 'The Household Service of Early Modern French Noblewomen', French Historical Studies, vol. 20, 1997, pp. 50-59; S. Chapman, 'Patronage as Family Economy: The Role of Women in the Patron-Client Network of the Phelypeaux de Pontchartrain Family', French Historical Studies, vol. 24, 2001, pp. 11-35.

${ }^{2}$ Kettering, 'The Household Service', p. 50. 
Not unnaturally, the sixteenth century is sometimes called the age of court culture, and Baldassare Castiglione's Il libro del cortegiano, published in 1528, was widely read, translated and discussed in Europe. ${ }^{3}$ Copious stories, devoted to the courts of European rulers and noblemen, ${ }^{4}$ also pay attention to the estates of the females. ${ }^{5}$

The Polish translation, more precisely, adaptation of Cortegiano, made by Łukasz Górnicki in Dworzanin polski in 1566, was the fifth in Europe, which reflects the status of the court in Poland (and in Lithuania). Nevertheless, a constituent part of manorial culture - the position of noblewomen's courts in Lithuania - has not been subjected to any detailed analysis, despite the growing number of studies of women's history. ${ }^{6}$ Research into the courts of Grand Duchess Elena, Queen Bona Sforza, Queen Barbora Radvilaite, and the Jagiellonian Princesses Katarzyna and Zofia supply some contribution to this field of history. ${ }^{7}$ Apart from the studies of Ivan Lappo (the publication of the 1552 register of the court of Kotryna Kločkienè, wife of the starosta of Žemaitija) and Urszula Augustyniak (on the courts of Lithuanian women and children in the seventeenth century), there have been no more works of this kind. ${ }^{8}$ Possibly this is due to the paucity of sources.

3 P. Burke, The Fortunes of the Courtier: The European Reception of Castiglione's Cortegiano (Cambridge, 1955).

${ }^{4}$ For a historiographical review of the works on Italian courts see, T. Dean, 'The Courts', The Journal of Modern History, 1995, December, vol. 67, pp. 136-151.

${ }^{5}$ There have been researches of both French and Italian manor societies and the position of women in them. The most recent work on the role of female clients and patrons in the courts of Renaissance Italy is 'Women as Patrons and Clients in the Courts of Quattrocento Italy' by E. S. Welsh, Women in Italian Renaissance Culture and Society, ed. L. Panniza (Oxford, 2000), pp. 18-24.

${ }^{6}$ For a review of related research, see I. Valikonyte, 'The Venets of Noblewomen in the Grand Duchy of Lithuania', Lithuanian Historical Studies, 1997, vol. 2, pp. 97-107; J. Sarcevičienè, 'Moterys', Lietuvos Didžiosios Kunigaikštystès kultūra. Tyrinejjimai ir vaizdai, ed. V. Ališauskas et. at. (Vilnius, 2001), pp. 397-412.

${ }^{7}$ For the composition of the court of Katarzyna Jagiellońka, see A. Przezdziecki, Jagiellońki polskie w XVI wieku (Cracow, 1868), vol. 3, pp. 311-326; K. Pietkiewicz, 'Dwór litewski wielkiego księcia Aleksandra Jagiellończyka (1492-1506)', Lietuvos valstybė XII-XIII a., ed. Z. Kiaupa, A. Mickevičius, J. Sarcevičienė (Vilnius, 1997), pp. 76; M. Bogucka, Bona Sforza (Warsaw, 1989), pp. 91-96; J. Pirożyński, Księżna Brunszwicka Zofia Jagiellonka (1522-1575) i jej biblioteka. Studium z dziejów kultury (Cracow, 1986); A. Marchwińska, 'Rejestr dworu królowej Barbary (15481551)’, Studia Żródtoznawcze, 38 (2000), pp. 81-102.

${ }^{8}$ I. I. Lappo, K istorii panskogo klassa v Velikom Kniazhestve Litovskom (Moscow, 1914), pp. 19-25; original in LMAB RS, f. 16, Nr. 6; U. Augustyniak, 'Dwory kobiece w Wielkim Księstwie Litewskim w XVII wieku', Mówiq Wieki, 1995, Nr. 4, pp. 11-14; eadem, Dwór i klientela Krzysztofa Radziwiłta (15851640). Mechanizmy patronatu (Warsaw, 2001), pp. 140-141. 
The composition of sixteenth-century noblewomen's courts, their officials and the functions performed by the servants are described scantily in the extant sources. The particularly valuable Žemaitian register of 1552 is the only primary record detected so far. This document presents the features of the court of a typical widowed noblewoman of the GDL. That Kločkiene belonged to the nobility is indicated by her wealth and the high post of her deceased husband the widow was one of the grandest noblewomen of the GDL. The dowry she brought to the house of her husband was 660,000 groats; after his death she inherited both his lands and a part of the holdings of the Hlebovičiai family. For the sake of comparison: the dowry of the wife of Vilnius palatine Elżbieta Szydłowecka Radvilienè was 12,000 florins (ca. 288,000 groats) in 1548; of Zofija Radvilaite Chodkevičiene, wife of the starosta of Žemaitija 590,400 groats in 1594 and of Ona Radvilaite Sapiegienè, wife of the GDL Chancellor 960,000 groats in $1599 .{ }^{9}$ It is possible that Kločkiene did not reach the level of the widow of the Vitebsk Palatine Ona Radvilaite Kiškienè, who provided as many as 407 horsemen in 1567; nonetheless she was among the richest noblewomen of her day. Therefore the list of her courtiers could be considered to illustrate the status of noblewomen's courts in the Grand Duchy of Lithuania.

This paper aims at illustrating the general composition of sixteenth-century noblewomen's courts and the functions of its courtiers on the basis of the register of 1552, references to the court found in correspondence, inventories drawn up after the death of its owner and individual acts. The general picture will not to be that of a specific court of a specific woman, but a reconstruction of a typical medium-sized estate owned by a married or widowed noblewoman. At the same time an attempt is made to determine the role of the noblewoman in appointing officials, co-opting courtiers and, in general, establishing the limits of her rights and patronage.

The Size of the Courts It is evident that the courts of sixteenthcentury noblemen were replicas of the court of the king. ${ }^{10}$ In the GDL likewise the courts of noblewomen were organized on the pattern of the courts of the queens of whom there were several -

9 T. Kempa, Mikolaj Krzysztof Radziwilt Sierotka (1549-1616) Wojewoda Wileński (Warsaw, 2000), p. 25; AGAD, Archiwum Radziwiłłów (henceforth $A R$ ), dz. XI, nr. 23, 30.

${ }^{10}$ S. Kettering, 'The Decline of the Great Noble Clientage During the Reign of Louis XIV', Canadian Journal of History, 24 (1989), p. 159. 
in the course of a century eight queens resided in Vilnius for a longer or shorter period: Elena, Barbara Zápolya, Elžbieta and Kotryna Habsburgietès, Barbora Radvilaitè, Anna Jogailaitè and Anna, wife of Sigismund Vasa. The princesses residing in Vilnius had their own courtiers too. A GDL noblewoman could always take the opportunity of getting acquainted with the hierarchical institution of the queen's court even without going to Poland (although such cases must have been rare). The queen's court usually consisted of two jointly functioning parts: a larger, male court, organized according to the model of the king's court, and smaller female quarters, closer to the queen. The queens' courts differed in size - this was conditioned to a great extent by the relations between the royal spouses. Elena's court comprised nearly 20 persons, that of Barbora Radvilaite as many as 200 and that of her predecessor Elizabeth of Austria, 114 people. ${ }^{11}$ The queens' courts in Lithuania yielded in size to those of noblewomen of the blood royal in Western Europe. In France the number of the courtiers of Jeanne d'Albert and Catherine de Bourbon varied between 116 and 263 in 1556 and 1600, and there were 464 courtiers in the service of Marie de Medici in 1606. The court of Catherine de Medici comprised 316 persons in 1569 and as many as 666 in 1585 (among them there were 80 ladies-in-waiting, called 'the flying squadron' by the ambassador of Venice). In actual fact, the court of the French queen almost equalled that of Sigismund Augustus - at one time the latter's court consisted of 752 courtiers, and including the masters-of-horse the total number was 1106 persons. ${ }^{12}$

The courts of renowned French noblewomen were smaller than those of the women of the royal family - they consisted of 20 to 30 courtiers. The situation in Lithuania was similar. According to the register of the courtiers in the service of the rich widow of the starosta of Žemaitija Kotryna Kločkienè their number was 57-60. That does not mean that all of them were present in the court all the time. Most probably the male attendants (who numbered about 20) were at the service of their patroness by rote. There are indirect indications that sometimes some noblewomen needed more courtiers. The size of the court depended on the social position of the noblewoman - on the post of her husband, her own role in the family and her personality.

${ }^{11}$ Pietkiewicz, 'Dwór litewski', pp. 94-95; Marchwińska, 'Rejestr dworu', pp. 81-102.

${ }^{12}$ Kettering, 'The Patronage Power', pp. 819-820; M. Ferenc, Dwór Zygmunta Augusta. Organizacja i ludzie (Cracow, 1998), p. 165. 
A minor noblewoman was attended by several persons, a married or widowed woman by up to several score. It is unclear how the situation changed in time. Due to the absence of sources it is impossible to determine whether noblewomen's court differed at the beginning and at the end of the sixteenth century - mention is made only of some court officials in the first half of the century. The previously less frequent reference to women's courtiers would lead to the conclusion that early in the century those courts must have been rather more modest. On the other hand, this sort of impression could also be accounted for by an inadequate preservation of records.

Finally it must be noted that female courts among the landowning gentry were much smaller, and served by one to five officials, and 'the unfree family' made up a separate part. A rather typical case is that of a rich gentlewoman, Nastasia Rodova, recorded in her will in 1569. This mentions the unfree family and the servants brought by herself, whom she willed to her daughter Zofia. The other married daughter Kozicka also received servants brought by her mother. It is noteworthy that unfree maids, somehow in contrast to the expected patriarchal attitude, were referred to by their mothers' names. The courtiers of the gentry woman are mentioned individually: Venclavas was given her black carriage, Vaitaškas and Karlas a bay horse with a saddle and a foal and, most importantly, the permission to serve in future 'whomever they wished'. The weaver Tomelis was permitted to go to his native place, Trakeliai. Rodova also released her maid Anuška. ${ }^{13}$ The wills of many other gentry women were similar. They indicated their unfree family and were certain to remunerate their courtiers. For example in 1578 Ona Moisejevičienè left her servant Adomas Chodakovskis some valuables and immovable property. Ordinary gentry women generally owned only their unfree family. Thus, in 1568 the landlady Barbora Juchnovičiene of Birštonas left her daughter Ona only the unfree people, who had served her, while in 1591 Kotryna Liaudbarienè released her unfree family, which she had inherited from her mother. ${ }^{14}$

The Courts of Minor Noblewomen Up to the present time only the practice of the Radvila family in administering the courts of the

${ }^{13}$ LMAB, RS, f. 31, Nr. 419.

${ }^{14}$ Kaunas Land Court Book, 1568-1570, Vilnius University Library, Manuscript Department (henceforth VUB RS), f. 7, nr. 25, ff. 24-24v; 1590-1592, VUB RS, f. 7, nr. 29, fo. 750; Žemaitian Land Court Book, 1578, VUB RS, f. 7, nr. 14576, ff. 176178. I would like to thank Lina Anužyte for bringing the latter source to my attention. 
children, among them of the girls as well, in the GDL in the seventeenth century, has been investigated. In the age of the 'Deluge' minors used to have courts of their own at an early age. The number of servants depended on the age of the child. These courts increased in the latter half of the seventeenth century. ${ }^{15}$ In the sixteenth century the situation was similar, although the custom to establish separate courts for children appeared most probably in the second half of the century. In selecting courtiers for their children, the noblewomen's role was significant. Even when the husband made a decision to divorce his wife, he usually left his children in her care and in the care of her court. Seeking not to lose his father's lands, the son of Grigalius Astikas, who was sentenced to death for treason in 1581 , indicated that 'early in his childhood his father separated him from his mother and he grew up alone'. ${ }^{16}$ According to the Third Lithuanian Statute (this custom was possibly followed also at the time of the First Statute) mothers were in charge of their children (and in particular of girls) until the age of seven. Special courtiers were appointed only for the sons who went abroad for the studies. Consequently, who took care of the daughters until they were married?

Before the birth of the child one or more midwives, in the sources referred to as biate glowy 'white heads' or simply baby 'old wives', were invited to noblewomen's courts. The nobles, e.g. the Radvilas of Dubingiai-Biržai, placed great trust in such women and their mothers-in-law during the pregnancies of their wives. Early in the seventeenth century, possibly after a miscarriage suffered by his daughter-in-law Zofija Sluckaite, the palatine of Vilnius Kristupas Radvila the Thunderbolt wrote about it to his son the vice-cupbearer of the GDL Jonušas Radvila. He expressed deep regret at the misfortune, appealed to Almighty God and at the same time consoled by recalling happy events in his life. He remembered the miscarriage suffered by his third wife Katarzyna Tęczyńska while she was had still been married to her first husband Prince Sluckis. His first wife Anna Sobkowna lost even twins after a fall. Afterwards, however, both wives of his gave birth to 'full-term healthy and very quick babies'. In both cases they were assisted by 'clever white heads and not by doctors'. In Radvila the Thunderbolt' words, it was those women who could pass on sensible advice and only they could be applied to. After her miscarriage, Tęczyńska was helped by 'an old

15 Augustyniak, 'Dwory kobiece', p. 13; eadem, Dwór i klientela, p. 138.

${ }^{16} L M$, Book Nr. 65, ff. 112-112v. 
lady of the first wife, a certain Mrs Gnilińska', who previously had participated at many deliveries and was very skilled. The first wife of Radvila the Thunderbolt' was helped at childbirth by several women, while her mother accompanied her on her way for a long time. ${ }^{17}$

The mindset of the noblewomen themselves was similar. In 1591 Elžbieta Sapiegienè sent her sister Eufemia Wiśniowiecka Radvilienè, wife of the Trakai palatine, 'a good and fortunate woman', who helped Eufemia to give birth to her son Mikalojus. When Ona Kiškaite, wife of Kristupas, son of Radvila the Thunderbolt, was giving birth in 1610, Elžbieta Sapiegienè sent her own horse and carriage 'to bring the woman sooner' to help her sister-in-law. ${ }^{18}$ After the delivery some midwives stayed for a longer time at the court to help take care of the newborn. 'The blessed hands of the white heads' were much sought after both by noblemen and noblewomen. A successful experience of the relatives, judgements about a particular woman's capability and reputation based on hearsay conditioned the choice of a midwife. When in 1583 the daughter Elžbieta of Radvila the Thunderbolt and Tęczyńska was born, 'Mrs Chłobrzeska took her to the duke who was very happy and kissed the daughter'. ${ }^{19}$ The correspondence shows that Chłobrzeska had been Tęczyńska’s servant for a long time. Thus, very young children were left in the care of their mother's courtiers, and no courts were established for them.

This sort of practice was adhered to even in the sovereign's family. The Jagiellonian Princesses Zofia, Anna and Katarzyna did not have any courts or personal courtiers of their own during their minority. Even when they were transferred to the so-called 'home of the princesses' in 1535, they were attended to by the courtiers and servants of Queen Bona. ${ }^{20}$ They acquired their courtiers only having reached majority, when they resided in Vilnius. In the noble families newborn babies and little children were looked after by their mother's courtiers for some time, too. The children of Radvila the Red were taken care of by Ona Chomecka, a courtier of his mother Barbora Radvilienė; subsequently Chomecka became a courtier of Kotryna Ivinska, wife of Radvila the Red. The nine children of the other Vilnius palatine Radvila the Black and his wife E. Szydłowiecka

${ }^{17}$ Radvila the Thunderbolt to Jonušas Radvila, s.l., s.d., AR, dz. IV, kop. 296.

${ }^{18}$ E. Radvilaite Sapiegiene to Kristupas Radvila, Vilnius, 14 March 1610, AR, dz. V, nr. 13893; E. Wiśniowiecka Sapiegienè to Tęczyńska Radviliene, Skodnia, 7 Nov. 1591, AR, dz. V, nr. 13879.

${ }^{19} \mathrm{~J}$. Bychowiec to unknown addressee, [1583], AR, dz. V, nr. 1759.

${ }^{20}$ M. Bogucka, Anna Jagiellońka (Wrocław-Warsaw-Cracow, 1994), p. 9. 
were reared (or their education was supervised) by the wife of Stanislovas Piekarskas, the marshal of the noblewoman's court. ${ }^{21}$

The situation and the courtiers did not change as long as both parents were alive. However, rare were the cases when children reached majority with at least one parent being alive, for life-expectancies could be very short. In the sixteenth century it was common for nobles to marry several times and it was rare for one spouse not to outlive the other. These circumstances influenced both the life of the minors and the circle of courtiers. The elucidation of the situation of the court orphans is a complicated matter. No lists of courtiers attending to the children have survived, and the extant documentation is patchy. The main source of related information is correspondence, usually undated, in which family issues were discussed. Genealogical information is also scarce and it is not always possible to establish which courtiers were entrusted with the care of which children.

A concrete example throws some light on these issues. In 1582 the marriage of the representatives of two most wealthy families in Lithuania - Radvila the Thunderbolt and K. Tęczyńska (Sluckienė) took place in Turcz. At that time Tęczyńska's children from her first marriage had already reached majority, while Radvila had a threeyear-old son, Jonušas, from his second marriage. There is no information about where the young Radvila was living at the time of the marriage. It is unclear whether the stepmother took care of Jonušas immediately after the marriage; however it is certain that after the birth of her daughter Elžbieta he was under her care. Elžbieta was born in October 1583, probably in Vsialiub. Soon afterwards both Jonušas and Elžbieta were settled in Turcz, and Tęczyńska hardly ever separated from her children. Early in 1584 she took them to Vilnius. In her letters she regularly informed her husband about a good health of both 'our children'. Only at the end of April 1584, when it became clear that her father-in-law Radvila the Red might die soon, she sent the little Elžbieta with several women to Šalčininkai. It is not clear whether Jonušas went with them. In January 1585 she again went to Vilnius with both children. The reports show that both children were raised together and attended by their mother's courtiers. The noblewoman herself was going to give birth once more, and her mother-in-law, coming from Volozhin to Vilnius, offered her help. There was concern that at that time Tęczyńska's

${ }^{21}$ R. Ragauskienè, Lietuvos Didžiosios Kunigaikštystès kancleris Mikalojus Radvila Rudasis (apie 1515-1584 m.) (Vilnius, 2002), pp. 152, 377; Kempa, Radziwitt Sierotka, p. 29. 
courtier Zborowska, who was considered experienced in these matters, was not in the court. ${ }^{22}$

After the birth of their son Kristupas in Svedasai on 15 March $1585,{ }^{23}$ both of the spouses' children of this marriage were in the care of their mother's courtiers. In June 1585 Elžbieta and Kristupas were looked after in Jašiūnai by the wife of Vilnius prefect Zofija Rotundiene, a client of the Radvilas. Their nurse pointed out that 'Master Kristupas, by the grace of God, is in good health and Miss Elžbieta is running a fever in the evenings, but not as high as previously. Thus, by the grace of God, she is merry and eats well'. ${ }^{24}$ Meanwhile, the six-year-old Kristupas is not mentioned at all in Tęczyńska's letters - maybe his father had taken charge of him at that time.

In 1585 there were changes in the life of the children. RadvilaPerkūnas took over the six- and four-year-old Zofia and Kotryna, daughters of his brother Mikalojus, palatine of Nowogrudek; the girls had been raised in his mother's court. The grandmother had been taking care of them after the death of her daughter-in-law Elena Radviliene in 1583. At first Mikalojus Radvila feared possible slander that 'their own father begrudges them bread', but on second thoughts he remembered that his sisters and half-sisters, who after Radvila the Black's death lived in the Czarnawczyce estate and had enough servants, led by Mrs Piekarska. He also deliberated whether or not a certain Czechanowska would be suitable for educating the girls, because their grandmother was not doing her duty to them properly. He wanted to appoint a permanent respectable courtier for his daughters. ${ }^{25}$

It is obvious that in 1585 there began the formation of a new court, that of the minors, to which the orphaned girls were taken. Although the choice of a courtier was debated by the girls' parents, the mother's word seems to have been decisive. At that time Rotundienè attended to the children. This educated woman, wife of the Vilnius prefect and starosta of Stakliškès, was a zealous Catholic,

22 Tęczyńska Radvilienè to Radvila the Thunderbolt, Turcz, [late 1583 - early 1584], Vilnius, 3 Feb., 19, 20 Apr.; 1584, 15, 27, 28 Jan. 1585, Biblioteka Narodowa w Warszawie (hereafter $B N$ ), mf. Nr. 4838.

${ }^{23}$ Augustyniak, Dwór i klientela, p. 14.

${ }^{24}$ Zofija Rotundienè to Tęczyńska Radvilienè, Jašiūnai, 18 June 1585; the letter is published in R. Ragauskienė, A. Ragauskas, 'Vieną ar dvi žmonas turëjo Augustinas Rotundas Meleskis ...', Lietuvos istorijos metraštis. 2000 metai, 2001, p. 32.

${ }^{25}$ M. Radvila to Radvila the Thunderbolt, Žiupronys, 20 March 1585, AR, dz. IV, kop. 503. 
while Radvila the Thunderbolt was a fervent Protestant. Thus, it was Tęczyńska, remaining Catholic after the marriage, who could invite Rotundienè. It is not clear how long Rotundienè looked after the Radvilas' children. The new nurse Kielczewska, doubtless, was a Tęczyńska protégée, besides, they were relatives. Kielczewska’s brother Kristupas Dzeržkas - a cultured man, speaking several languages and serving as a royal secretary - was Rotundus' son-inlaw. Kinship ties with Rotundas helped not only Dzeržkas' sister but also Dzeržkas himself to come to Radvilas' court. Dzeržkas was an eager Radvila the Thunderbolt' client, he even advised him in selecting his fourth wife. It is believable that Kielczewska came to court in the standard patronage way - through a relative's intercession. Dzeržkas wrote that it was the duchess and not Radvila who invited Kielczewska to look after the children:

I am very well informed by honest people how dearly the wife of His Ducal Highness, Her Worship the deceased duchess, worthy of eternal memory and full of sacred virtues, loved and valued my sister Mrs Kielczewska for her diligent service, was favourably disposed towards her and promised to make provision for her.

After the death of her patroness in 1592 she continued serving the duke's children and protected 'the health and honour' of Radvila's daughters. Kielczewska's service ended around 1599. Due to the machinations of the senior Radvila's servant she asked through her brother to be released from court and properly remunerated. ${ }^{26}$

Radvila's infant daughter and her nieces were reared by several courtiers, whose number increased after Tęczyńska's death in 1592 . At that time Radvila the Thunderbolt married (for the fourth time) the childless sister of his second wife Elžbieta Ostrogiškaitè. It is noteworthy that the new stepmother was not separated from Radvila the Thunderbolt' daughter and her nieces. The girls stayed with their stepmother even when their father fell out with his new wife in 1596-1597. The noblewoman then lived in her estate at Vyžuonos with Radvila the Thunderbolt' daughter Elžbieta and, possibly, with her nieces. ${ }^{27}$ It is unclear where the twelve-year-old Kristupas lived at that time. In his letters Radvila the Thunderbolt did not refer specifically to his children: in 1597 he authorized his servant

${ }^{26}$ Dzeržkas to Radvila the Thunderbolt, Stakliškès, 25 Jan. 1599, AR, dz. V, nr. 3515 .

${ }^{27}$ Both the daughter and the wife sent letters to Radvila the Thunderbolt at the same time from Vyžuonos: Elžbieta to her father on 23, 26 Jan. and 12 Feb. 1597; the wife to her spouse on 20 Feb. and 26 March; BN, mf. 4838. 
Baltromejavičius wife to go from Užpaliai to Vyžuonos, at the same time indicating that Jonas Bochovskis should stay with the children in case the noblewoman would not take them with her. ${ }^{28}$ It is possible that even staying with the stepmother Elžbieta Radvilaite enjoyed the service of one or more courtiers. Thus, it is already possible to speak about the formation of a separate minor's court.

Other minor noblewomen, reared by their relatives after the loss of their parents, also had several female courtiers. Sometimes a mother even used to indicate in her will that she would not want a stepmother bossing her daughter around and consequently entrusted her to a guardian. Before her death in 1591, Leonas Sapiega's first wife Dorota entrusted her daughter Barbora (from her first marriage to Duke Steponas Zbaražskis) to her cousin the wife of the Vilnius palatine.

Therefore, wishing that in her young days she would receive proper instruction and education until she reaches her majority and until the good Lord sends her a friend, I request my cousin, the wife of Vilnius Palatine, my beneficent mistress and sister ... to care for my little daughter Basia ... and graciously house her and keep her at her own side, because it would be most beneficial for her to be with Her grace. ${ }^{29}$

In 1562 E. Szydłowiecka asked her husband not to keep their daughters at his own side, 'so that the other mother would not lay the law to my children'. She asked the aforementioned Piekarski's wife to take care of her youngest children - daughter Kristina and son Stanislovas. It is known that three of her daughters until marriage lived in the Jarosław estate in the custody of the wife of the castellan Jan Krzysztow Tarnowski, who died in 1567. In such cases girls usually had several courtiers who had come with them from the home of their parents. Radvilas' daughters were attended to by their long-time servant Mrs Kozicka. Her death early in 1570 was a severe blow to the palatine's daughters and they asked their brother Radvila the Orphan to appoint Mrs Piekarska as their guardian without delay. In their letters in 1568 they wrote about a certain Mr Okregglicki and asked to send him with their brothers to Germany 'to serve there and learn the language of that country and other skills'. ${ }^{30}$

${ }^{28}$ Radvila the Thunderbolt to Baltromejavičius, Vilnius, 16 Feb. 1597, AR, dz. IV, kop. 291.

${ }^{29}$ S. Lazutka, Leonas Sapiega (Gyvenimas, valstybinè veikla, politinès ir filosofinès pažiūros), (Vilnius, 1998), pp. 71-73.

${ }^{30}$ Kempa, Radziwitl Sierotka, pp. 29, 46; Ona, Zofija and Kristina Radvilaite to Radvila the Orphan, Jarosław, 6 Sept. 1568, 14 Jan. 1570, AR, dz. IV, kop. 737. 
Thus, already in the sixteenth century minors of both sexes were reared by their mothers' female courtiers. The opinion of the noblewomen was instrumental in their choice. Some information on individual small courts of minor girls goes back to the latter half of the sixteenth century. The judgment of the noblewomen also seems to have been crucial in appointing court administrators. In the case of the mother's death, the girls were generally educated until their marriage by the relatives or persons selected by the mother. The girls used to come to the new places with their former courtiers, whose replacement depended on the decision of their patrons - uncles, brothers, etc. The girls stayed with their patrons until marriage. Once they had come of age, these girls could put in a word for a particular courtier, thus gradually entering into clientele relationships.

\section{The Structure and Formation of Noblewomen's Courts Such} courts, functioning as an entity, usually consisted of several parts: court officers, the male quarters (male courtiers and messengers), court specialists (physicians, clergymen and musicians), the female quarters (ladies, maidens and servants) and the court staff (servants, craftsmen, coachmen, etc.). This kind of division is slightly artificial, because it is even difficult to define more precisely the structure of the courts of noblemen or the sovereign. For example, there is no unanimous opinion about the treatment of royal secretaries as members of the court or the attribution of some professions (physicians and clergymen, serving in the court) to a particular category and whether clients were courtiers or not. Beyond doubt, the structure of the female courts was similar to that of the queen and differed from the male courts in that that the women's role in the former was more significant. In this paper an attempt is made to present the features of a typical GDL noblewoman's court in the sixteenth century. A particular court may not always comprise all the components or have all the officials. The queen's courts could also vary. For instance, only Barbora Radvilaite had guards in her court, and the noblewomen's courts could differ too.

There is no information about who formed the married noblewoman's court - the lady herself, her husband or her parents. The appointments to Queen Barbora Radvilaite's court were influenced by men: the king, his adherents and her brother. Some courtiers were inherited by the queen from her former court or that of the Radvilas. ${ }^{31}$

${ }^{31}$ Marchwińska, 'Rejestr dworu', p. 86; R. Ragauskiene, Barbora Radvilaite (Vilnius, 1999), p. 139. 
Most probably a similar process must have taken place in forming a court on the first marriage. Speaking about their courtiers the noblewomen always indicated one or two of their courtiers, who had served them since their early days and, consequently, whom they had inherited from the court of their parents or patrons. The Duchess Aleksandra Wiśniowiecka Radvilienè, wife of the Nowogrudok palatine, mentioned 'the old court lady, my maidens, and servants' in her will. ${ }^{32}$ Relations between the spouses worsening, the husband limited his wife's functions and intervened in the formation of her court. In 1596-1597, being at odds with his wife E. Ostrogiškaitè Radvilienè, Radvila the Thunderbolt ordered his servant Petras Orechovinskis to follow every step of the noblewoman, to let him know everything and to prevent her from meeting Catholic priests and people from the Ostrogiškis milieu. The servants of the former wife of the starosta of Žemaitija Jonas Kiška were persecuted and bribed in the new court. Radvila obliged his servant to ask $\mathrm{Mr}$ Czekanowski that on any occasion he would write without delay, 'because we know that our wife does not keep secret anything from his wife'. The nobleman co-opted his people into the court of his wife and surrounded her with persons faithful and devoted to him - Pakošas, Orechovinskis, Dubina, Tolkačius, Endrichas, and others. ${ }^{33}$ Interestingly, imitating his father's behaviour towards his wife Ona Kiškaite, the youngest the Thunderbolt' son Kristupas Radvila (1585-1640) similarly treated his wife, too. ${ }^{34}$ The difference was only in that that this type of Kristupas' behaviour has been described by historians in great detail, while that of his father towards his fourth wife is much less well-known.

On becoming a widow, a noblewoman would reorganise her court. Using her own discretion, she not only employed new courtiers and appointed officers, but also engaged some of her husband's former courtiers, who were loyal and dedicated to her. Sources very often refer to courtiers, moving from the deceased nobleman's court to that of his widow.

(1) Court Officers Several officers from the noblewomen's courts are mentioned in the sources. The highest hierarchical positions were occupied by court marshals or senior servants. Thus in 1541 the court of Elžbieta Radviliené, the widowed wife of the Vilnius pala-

${ }^{32}$ A. Wiśniowiecka Radvilienè's will, Grodno, 18 Nov. 1573, AR, dz. XI, nr. 21.

${ }^{33}$ Radvila the Thunderbolt to Petras Orechovinskis, Bielica, 26 Oct. 1596, AR, dz. IV, kop. 291.

${ }^{34}$ Augustyniak, Dwór i klientela, p. 142. 
tine, was managed by the court marshal Stanislovas Bartoševičius, ${ }^{35}$ and the senior Tęczyńska's servant was Józef Bychowiec, at least between 1582 and $1585 .{ }^{36}$ Judging from the duration of the service and the place in the list, the most senior in Kločkiene's court was Jonas Zabiela, who previously had served the starosta for as many as 30 years. These duties ensured decent living conditions even after the death of the patroness and guaranteed successful careers for the children and relatives. For example, after the death of his patroness Stanislovas Bartoševičius moved to the court of J. Hlebavičius, Palatine of Vilnius, while his son, becoming a royal secretary, managed to occupy a top post in the administration of the GDL. Information is lacking about Bychowiec's fate. Nevertheless it is unquestionable that the Bychowieces, who served Tęczyńska's husband Radvila the Thunderbolt and their sons, were related to this noblewoman's servant. Having revealed oneself as an able official one could enter a client-patron relationship and perform special duties. Most probably due to these links these same Bychowieces could rise to the status of senators in the latter half of the seventeenth century. ${ }^{37}$

The letters of the senior servant Bychowiec, whose duty was to supervise the work of the courtiers in Turcz, reveal the functions of the officials. Practically, the running of the whole court was in his hands: Bychowiec informed the duchess about the noble girls taken away from the court, courtiers' health, behaviour and relations with the noblewoman's sons and about the events at the court; he also took care of the surroundings. Thus in 1582 in Slutsk he had cages installed for lions, organized the work of the craftsmen, distributed the duchess's commissions and was instrumental in appointing new servants. It is not clear whether within the confines of the law he advised the duchess on the documents necessary for the law court and asked her during her stay in Poland to have onions and cucumbers bought 'for the Lithuanian estates, because in Poland that is easier than in Lithuania' ${ }^{38}$ In short, Bychowiec was a kind of private eye for the duchess.

The sources speak about two more court officers in addition to the senior servant, namely the treasurer and the clerk or secretary.

${ }^{35}$ Radviliene's law suit against the palatine of Trakai J. Zaberezinskis, 30 June 1541, LM, Book 27, f. 105v.

${ }^{36}$ Bychowiec to the duchess K. Tęczyńska, letters of $1582-1585, \mathrm{AR}, \mathrm{dz}$. V, nr. 1759.

${ }^{37}$ Ragauskienè, Lietuvos Didžiosios Kunigaikštystès, p. 308; Augustyniak, Dwór i klientela, pp. 81, 122.

${ }^{38}$ Bychowiec to Tęczyńska, Skirmontowo, 4 March 1583, AR, sz. V, nr. 1759. 
The noblewoman had her own coffers, supplemented by the incomes from her estates. She held the purse-strings, therefore the treasurer was a necessary and very important person. The sources also mention the noblewoman's clerk - d'ak or khlopets - who made out receipts and registers. These two officials had ample work to do: they received revenues and paid the courtiers salaries fixed by the noblewoman, etc. Dealing with large sums of money they had to be dedicated and devoted to their patroness. For example, among the various expenses of Zofia Chodkevičienè of Melc, wife of the GDL deputy cup-bearer, one can find sums paid to her officers, servants and other attendants in 1597. According to a Tribunal decree the descendants of a certain Svidečka were paid $700 \mathrm{zl}$, Mr Karčamskis - 150 zł., Mr Zaviša - 300 zł., Viktorovskis - 64, Mr Kžekavskis - even 3,500 zł., Mr Manščinas - 329 zł., etc. ${ }^{39}$ These two persons, the noblewoman's treasurer and clerk, whose names we don not know, paid out as many as 6,265 zł.. Duchess Fedora Sanguškaite Leščinska, wife of Brest (Kujawy) palatine, also mentioned in her will courtiers, who administered her financial matters. Allowing her third husband Andrius Leščinskis to use her estates, she indicated that he could collect taxes, increase revenue, audit the accounts of the officials and make out the receipts. She singled out Mrs Ona Redowska, who having collected taxes from various people, had not handed 7,000 zł. over to her; she also mentioned a certain Kunitski as a manager of her financial affairs. ${ }^{40}$

The duties of the treasurer, the clerk and the senior court officer did not end with the death of their patroness. As the wills and posthumous property inventories witness, they transferred the noblewoman's property to the heirs. Jonas Zabiela, d'ak Motiejus Šavula and treasurer Semionas Mochaila as courtiers of the childless wife of the starosta of Žemaitija after her death in 1552 participated in the transfer of her property to the royal clerk Ostafijus Valavičius. The deceased noblewoman's relatives the royal cup-bearer Matysas Petkevičius, Stanislavas Hlebavičius, Motiejus Lopata and Martynas Šemeta were also present at the handover. On 15 October 1552 debts were paid off to Kločkienè's courtiers for their service. A posthumous inventory of the belongings of Ul'ana Bogušovna Hornostajeviene, which were in the Timkovichi estate, was drafted by her servant Ostafijus Žukas on 26 December 1575 . He enumerated the papers

${ }^{39} \mathrm{BN}, \mathrm{mf} .7886$.

${ }^{40}$ LMAB, f. 16 , Nr. 85, f. 16. 
found in the chests and Lev Bogotivin's receipt, presenting his accounts according to his function with respect to the duchess's Timkovichi and Grozov lands and the Blevčickas estate. Meanwhile the noblewoman's domestic Petr Andreevich Kozhushka was 'aware of the situation' and had keys to the barn where various things were kept. ${ }^{41}$

The noblewomen's private secretaries (clerks) could also be officers. In Western Europe no less than a quarter of all women's letters were written in the hand of their secretaries in modern times. A large network of women's correspondence and a comparatively great number of letters in the second half of the sixteenth century, the observance of accepted formats, the use of several languages, and so on, attest to the importance of personal secretaries for noblewomen in the Grand Duchy. In the court these were very necessary officers, and they were among the most reliable ones - they were familiar with many things related to the patroness and, consequently, they were influential. They had to write dictated letters and read or translate in-coming ones. Some women, occupying the highest posts in the country, even had their own chanceries with several secretaries and clerks. Thus, Tęczyńska's client asked her to send him some necessary documents 'from her chancery'. Possibly that is why the sources more often refer to the secretaries of one or another Lithuanian noblewoman. The clerk of Zofia Goštautiene, wife of the GDL chancellor, was Stanislovas Komarovskis; the clerk Mikalojus Janovickis, who had served the castellan of Vilnius until his death in 1541, afterwards remained in the service of the widow Barbora Radvilienè. The clerk Sava, who was in Tęczyńska's court in 1581, was recommended to her by her courtier Zofia Trizniene. ${ }^{42}$

(2) The Male Quarters: Courtiers and Messengers Numerically it was the largest part of the court. It comprised the male courtiers, the main retinue of the noblewoman, the attribute of her prestige; they also acted as messengers. The sources refer to them as 'courtiers', 'attendants' or 'servants'. A list of 1552 shows that no less than 23 (26-27) persons of this category were in the service of Kločkienè. 'Those who could not come, in particular the ailing ones, should be added to those 23 in the list; 1,620 groats were earmarked for them. The number is quite impressive, though it seems that not all the

${ }^{41}$ LMAB, f. 16 , Nr. 9, f. 1-5.

${ }^{42}$ On the noblewomen's secretaries, see R. Ragauskienè, A. Ragauskas, Barboros Radvilaitès laiškai Žygimantui Augustui ir kitiems. Studija apie XVI a. Lietuvos Didžiosios Kunigaikštystès moteru korespondencijq (Vilnius, 2001). 
courtiers were present with the patroness at the same time. Their primary duty was to participate in solemn escorts and to accompany her in frequent trips and to perform some special tasks. Thus, after the death of the GDL land treasurer Dimitras Chaleckis in 1594 his wife Regina Chalecka sent her servants Maslovskis and Beresnevičius to the sovereign to confirm the merits of the deceased. ${ }^{43}$

The disagreement between Radvila the Thunderbolt and his fourth wife Elžbieta Ostrogiškaite shed some light on the courtiers' everyday life in 1596-1597. A year after his marriage in 1594 Radvila won a lawsuit against his father-in-law over the lands which were to become the property of his son Jonušas from his marriage to Kotryna Ostrogiškaitè. Afterwards this nobleman endeavoured to make his fourth wife bequeath him the lands which belonged to her for life. The disagreement grew into a conflict in 1596-1597. The wife was strictly controlled, her contacts with Catholic clergymen were restricted; in general, a period of mutual mistrust began with secretive activities and intrigues against each other. Despite her husband's control the noblewoman retained in her court a number of her former courtiers, loyal to her. Radvila often mentioned those courtiers. He jeered at some of them ("what concerns that Mikulia, now called pan Mikulich'), and sought to entice others away by bribes. He instructed Orechovinskis to be as affable as possible to Chmieliovskis, attending to his wife. Still others were used to follow the movements of his wife's servants. He specially sent his wife's courtier Pučka to Vyžuonos and wrote to his agent 'let him live there, ... and let Dubna look after him'. When the duchess wanted to send him with her letters, those letters were to be taken from him. ${ }^{44}$

Little is known about the ways of recruiting courtiers. There is some information about noblewomen's mediation in recommending a particular person for the courts of their husbands, relatives or friends. Such intercessions witness an active role of the noblewomen in selecting courtiers. For example, the duchess Tęczyńska Radvilienè accepted the son of Jan Grot, the Drutsk judge, and afterwards sent him to her son Aleksandras Slutskis' court. ${ }^{45}$ Having spent some time in the court of a high-ranking GDL noblewoman and having proved nr. 1809 .

43 Chalecka to Radvila the Thunderbolt, Rozanka, 13 March 1598, AR, sz. V,

${ }^{44}$ Elžbieta Ostrogiškaitė was the sister of Radvila's second wife, a widow of Jonas Kiška, a devout Catholic; cf. H. Lulewicz, 'Radziwiłł Krzysztof zwany Piorunem h. Trąby (1547-1603)', Polski Słownik Biograficzny, 1987, t. 30, p. 274; Radvila to Orechovinskis, Bielica, Oct., 1596; Radvila to Bartlomejevičius, Vilnius, 30 Dec. 1596, Žirmūnai, 23 Oct. 1597, AR, dz. IV, kop. 291.

45 Grot to Tęczyńska Radvilienè, Duplewiczi, AR, dz. IV, nr. 4771. 
himself to be an accomplished courtier, he could count on a position of a courtier in her husband's court after the death of his patroness. Thus, Mr Kochanowski, having served for Tęczyńska Radvilienė, moved on to the court of Radvila the Thunderbolt; a foreigner Bartolomeo Faragoi, having served for Elžbieta Eufemia Radviliene since his early days, afterwards became a servant of her husband Radvila the Orphan. ${ }^{46}$

The data about the origin of the noblewomen's courtiers are scarce. Even the list of 1552 indicates merely the origin of the female servants. Possibly it was taken for granted that the noblewoman's courtiers could be only from the gentry. That is supported by some facts. In correspondence persons of this category were sometimes labelled as pan. True, in his letter Radvila the Thunderbolt never gave full names to either his servants or those of his wife, he used only the surname: Roznowski, Kotlinski, Kamenski, etc. Meanwhile it is certain that at least some of the courtiers of the duchess Bogushovna Hornostajevienè were gentlemen. In compiling a property inventory of her residence in Timkovichi after her death in 1575 eight of the courtiers had seals, indisputable proofs of their noble origins. That does not mean that all of them were literate. In addition to P. Kožuška and the clerk O. Žukas, only Jermola Galaunè and Grigorijus Sujata could scrawl their signatures. Most probably illiterate Motiejus Jablonskis, Kondratas Dručaninas, Petras Kožuška and Povilas Nedvedskis only affixed their seals to the document. ${ }^{47}$ Therefore, the male environment of the GDL noblewomen does not seem to have been very enlightened.

On the death of the patroness, accounts were squared with the courtiers according to the length of the service and the merits. This formula can be found actually in every noblewoman's will. In her will in 1555 Ona Davainaite, wife of the royal equerry Jarošas Korickis, asked her husband 'to let the pan domestics and the pani domestics, who served me for a long time, graciously and gainfully go and be each rewarded for their services to me according to their merits'. ${ }^{48}$ A list of Kločkienè's courtiers gives a clue to what was meant by 'according to the merits'. Length of service was taken into account, but that did not always define the amount of the allowance. Thus, Ivan Polonskii, having served since his early days, and V. Grubickii,

${ }^{46}$ A. Firlei to Tęczyńska Radvilienè, Lublin, 18 Nov. 1598; Firlei to Radvila the Thunderbolt, AR, dz. V, nr. 3763; Kempa, Radziwitl Sierotka, p. 205.

47 LMAB, f. 16, Nr. 9, ff. 1-5.

${ }^{48}$ LM, Book Nr. 43, f. 21. 
having worked for 20 years, received barely 180 groats each, while J. Długoborski or M. Pilichowski, newly accepted and having spent only a year in the court, were paid from 360 to 480 groats each. In these matters some other criteria must have been significant, possibly the reliability, origins or personal likes and dislikes. All the same, Jokubas Krasuskis, even having carried out the land reform, received only 180 groats for his three-year service.

Table 1: Kotryna Kločkienè's Court Officials, Courtiers and Specialists in 1552

\begin{tabular}{|l|c|c|}
\hline \multicolumn{1}{|c|}{ Courtier } & $\begin{array}{c}\text { Years of } \\
\text { service }\end{array}$ & $\begin{array}{c}\text { Reward } \\
\text { (in groats) }\end{array}$ \\
\hline 1. Jonas Zabela & & \\
2. Jurved both lords) & 30 & 1,500 \\
3. Motiejus Šavula (d'iak) & 18 & 720 \\
4. Laurynas Zukovskis & 8 & 900 \\
5. Semionas Mochaila & 12 & 720 \\
(treasurer) & 8 & 720 \\
6. Motiejus Šošas & 10 & 480 \\
7. Motiejus Kosekas & 2 & 240 \\
8. Viktorinas Chmelevskis & 10 & 300 \\
9. Janas Dlugoborskis & 1 & 360 \\
10. Jokubas Krasuskis & & \\
$\quad$ (also a land-surveyor) & 3 & 180 \\
11. Martynas Pilichovskis & 1 & 480 \\
12. Stanislawas Picekas & 10 & 600 \\
13. Jokūbas Lisavskis & 2 & 300 \\
14. Jonas Cebrovskis & 3 & 480 \\
15. Jonas Stebkovskis & 1 & 480 \\
16. Andrius Ruseckis & 1 & 360 \\
17. Andrius Karbovskis & 10 & 360 \\
18. Feliksas Duchnovkis & 7 & 120 \\
19. Danielius Diadkovskis & 4 & 120 \\
20. Jonas Breznickis & 15 & 120 \\
21. Mikalojus Breznickis & & \\
$\quad$ (a clergyman) & 17 & 60 \\
22. Malcher Strelec & 4 & 180 \\
23. Vitas Trubickis & 20 & \\
& & \\
\hline
\end{tabular}




\begin{tabular}{|l|c|c|}
\hline \multicolumn{1}{|c|}{ Courtier } & $\begin{array}{c}\text { Years of } \\
\text { service }\end{array}$ & $\begin{array}{c}\text { Reward } \\
\text { (in groats) }\end{array}$ \\
\hline 24. Stanislovas (a barber surgeon) & 10 & 60 \\
25. Ignas Pavlovičius & 15 & 180 \\
26. Mikalojus Čechas & 5 & 120 \\
27. Vaska Suchiničius & 1 & 50 \\
28. Ivanas Polonskis & served since & 180 \\
& his early days & \\
\hline
\end{tabular}

In the male quarters an intermediate position between the courtiers and the messengers was occupied by dwarves, who became popular in the noblewomen's courts in the latter half of the sixteenth century. Both male and female dwarves had served in the noblewomen's courts since the beginning of the century. A page of Barbora Radvilaite was the dwarf Okulinskis, and there were also two female dwarves Katarzyna and Zofia. Queen Bona Sforza was attended by the dwarf Marina, who had a house in Narov; in 1562 the sovereign released her from paying tax on that house. A secretary of the Brunswick duchess Zofija Jogailaitè was the dwarf Agnieška. In 1562 Kotryna Jogailaite went to Finland with her dwarves Macek, Semionek, Doszka and Baszka. ${ }^{49}$ The noblewomen developed this custom in their courts. In 1581 Radvila sent Tęczyńska a dwarf, who had served the Moscow duchess and had a beard 'nearly longer than he himself'; and Radvila's father, palatine of Vilnius, was going to send the duchess one more 'very small' man. After some time other noblewomen became interested in the dwarves. The wife of the starosta of Žemaitija, staying with the duchess, kept enquiring about the Muscovite dwarf. ${ }^{50}$

In the 1552 list the messengers of the noblewoman are presented separately. Their lower rank is indicated by the ratio between their salaries and the duration of service as well as by the way of writing their names. The requirements in the recruitment for this category seem to have been less demanding. Noble origin was not a necessary condition, the messengers Staska and Kavelis seem to have been commoners, maybe even peasants. Nonetheless,

49 LM, Book 44, ff. 48v-49; Pirożyński, Księżna, p. 43; Przezdziecki, Jagiellonki, pp. 325-326.

${ }^{50}$ Triznienè to Radvila the Thunderbolt, Ostashino [1581], AR, dz. V, nr. 16475; Radvila to Triznienè, s.l., [1581], AR, dz. IV, kop. 289. 
there were gentlemen among the messengers as well. Kločkienè's messengers Fedoras and Sila Skrobotas, most probably, were related to the noblewoman's client Petras Skrobotas. The noblewoman remained indebted to him $115 \mathrm{zl}, 3180$ groats and a silverplated sabre. Interestingly, that unnamed Skrobotas subsequently became Radvila the Red's messenger, and the lieutenant of one of his estates was Martynas Skrobotas. That could be a mere coincidence of the surnames, though career matters cannot be discarded either.

It is scarcely surprising that the number of the messengers was relatively large - as many as nine out of ninety courtiers. That was due to the increasing communication and, generally, to the noblewoman's activity. A similar number of messengers served for other noblewomen. In this respect their courts did not differ much from those of the noblemen. At one time Radvila the Red had twelve messengers - about seven per cent of the total number of the courtiers. However, the information about this group is most vague. People delivering letters, documents and other packages are referred to only in respect to the contents of the parcel. Therefore we can only learn that the wife of the palatine Goštautas had a messenger by the name of Ščiužinskis, that Kalèda was a courier of the Vilnius castellan's wife, that the messenger Piašečkis served Tęczyńska Radvilienè, etc. ${ }^{51}$

Table 2: Kotryna Klockienè's court messengers in 1552

\begin{tabular}{|l|c|c|}
\hline \multicolumn{1}{|c|}{ Messenger } & Years of service & Reward (in groats) \\
\hline 1. Ostafijus Klizčickis & 3 & 180 \\
2. Sebastijonas Karskis & 9 & 60 \\
3. Targovskis & 3 & 120 \\
4. Staska & - & 50 \\
5. Fedoras Skrobotas & 2 & 60 \\
6. Sila Skrobotas & 2 & 60 \\
7. Motiejus Strizka & half a year & 30 \\
8. Kavelis & 6 & 60 \\
9. Jankovskis & 1 & 60 \\
\hline
\end{tabular}

${ }^{51}$ Firlei to Tęczyńska Radvilienè, Zanovc, 1 July 1581, AR, dz. V, nr. 3763; B. Radvilienè to her son, Vilnius, ca. 31 May 1547, AR, dz. IV, kop. 636. 
(3) Court Specialists: Physicians, Clergymen and Musicians The 1552 list mentions the noblewoman's chaplain Mikolajus Breznickis and the blood-letter Stanislovas. That would correspond to the situation in the noblewomen's courts, in which the chaplain and lower-rank physicians were attributed to the male quarters. The situation was similar in other noblewomen's courts. After becoming a Protestant, E. Szydłowecka Radvilienè even had several chaplains. Before her death in 1562 she 'invited the preachers and talked with them'. Radvila the Thunderbolt prevented his wife's communication with a certain priest Vysockas, her confidant. ${ }^{52}$ Court chaplains were personal confessors, they attended noblewomen on their patroness' funeral. It was Kločkienè's chaplain who conducted her funeral ceremony. 'The funeral train and bell-ringing out cost 900 groats in Roman Catholic churches and 260 groats in Orthodox ones.' The functions of court clergymen differed from those in the Catholic, Orthodox or Protestant churches funded by noblewomen on their estates. The patronesses' contacts with the church priests are described in the sources in greater detail than those with these often unnamed priests in their courts.

The services of medical attendants were very popular in the sixteenth century. That is attested by an unnamed inventory (most likely a posthumous one of Konstantinas, the son of the Trakai castellan Jurgis Chodkevičius), in which as many as four silver vessels for blood-letting were indicated. In 1562 the medical attendant Aleksandras served the royal family in Vilnius, while the blood-letter Stanislovas was taken to Finland by Kotryna Jogailaite. ${ }^{53}$ Women's letters often dealt with health matters and that leads to the conclusion that the links between the noblewomen and the medical people were common. Qualified physicians were frequent visitors in the court. However, it is unclear whether they were hired for a certain period and received professional fees or were employed as permanent salaried courtiers. The wife of the Vilnius palatine Radvila was attended by several most highly qualified doctors. In June 1562 her health was tended by the German doctor Rupert Fink and his attendants in the Lukiškès court. Before her death this noblewoman bade farewell to her doctors saying that with her demise she would

${ }^{52}$ Radvila the Thunderbolt to Orechovinskis, Sialets, 25 Oct. 1596, AR, dz. IV, kop. 291.

53 'Register of the belongings of the deceased pan Konstantin', [1571], LMAB, f. 16, Nr.7; LM, Book Nr. 260, f. 274; Przezdziecki, Jagiellonki polskie, p. 326. 
relieve them of their troubles. ${ }^{54}$ Fink was also her husband's doctor. Through his belonging to the Radvila clientele, Fink subsequently became a royal physician. With the Radvilas' intercession he received the Rokantiškès estate and finally married his daughter Zuzana to Radvila's client Jokubas Volanas around $1584 .{ }^{55}$

In other noble families doctors also attended to several members. Thus, Radvila Perkūnas sent his physician to his wife (with whom he was at odds) to take care of her health (or possibly, more precisely, to keep an eye on her). In his letters he instructed his reliable servant Orechovinskis to write the doctor that the duchess allegedly complained about his utter foolishness and indifference to her illness. ${ }^{56}$ It was an evident attempt to set off the patient against his doctor.

Personal physicians attended Tęczyńska in Vsialub, where she lay in childbirth in 1583 and the wife of the GDL marshal Zofia Radvilaite Dorohostaiska, who died in 1614. Her husband Kristupas Monvidas Dorohostaiskis' will contained a reminder to pay $300 \mathrm{zł}$. to his wife's physician Markas Eugerijus. ${ }^{57}$

The noblewomen patronized the physicians; however it is not clear whether they were their clients or courtiers. Characteristically cliental letters were written to Tęczyńska by the physician Stanislovas Sabina. ${ }^{58}$ The wife of the Kiev castellan Aliona Chodkevičiūte Sapiegiene sold the court and town of Pervalka to the doctor Bukcelis for 90,000 groats. ${ }^{59}$ Again it is unclear whether the noblewomen made use of the services of these medical people.

In the sixteenth century it was customary to have a choir, a dancing master and musicians at the courts of the sovereign and nobles in the GDL. Thus, Radvila the Orphan had an organist, Negro drummers and trumpeters, and Leonas Sapiega had a number of musicians, too. ${ }^{60}$ The sources are scarce on this issue in relation

54 S. Kot, 'Nieznany poeta polski XVI wieku', Zeitschrift für slawische Philologie, 25 (1956), pp. 133, 138; LM, Book Nr. 260, ff. 273v-274.

${ }^{55}$ Book of Kaunas Land Court, 1590-1592, VUB, RS, f. 7, nr. 29, f. 735; on 5 Apr. 1574 Henri Valois assigned Rokantiškès to Doctor Fink. LM, Book Nr. 51 (1566-1574), Book of Inscriptions 51, ed. A. Baliulis et al. (Vilnius, 2000), pp. 330-332.

${ }^{56}$ Radvila the Thunderbolt to Orechovinskis, Sialets, 20 Oct. 1596, AR, dz. XI, nr. 23 , f. 79.

${ }^{57}$ Radvila the Thunderbolt to his wife, Biržai, 12 Sept. 1583, AR, dz. IV, kop. 289; AR, dz. XI, nr, 23, f. 79.

${ }^{58}$ Sabina to Tęczyńska Radvilienè, [1585?], AR, dz. V, nr. 13684.

${ }^{59}$ LM, Book Nr. 275, ff. 278-278v.

${ }^{60}$ I. Bieńkowska, ‘Muzycy Lwa Sapiehy’, Barok, 5 (1998), pp. 39-49. 
to noblewomen's courts. The list of Kločkienè's courtiers does not present any concrete evidence. Nevertheless, E. Szydłowecka makes a mention of the daughters' dances after her death - consequently there must have been musicians in their courts. In Tęczyńska's court there was an organist, serving on the basis of an individual contract. In 1582 he was paid 20 zł. by Tęczyńska’s order. A brilliant lute player Stanislovas was kept by the wife of the chancellor Sapiega in 1602. His professionalism is attested by the excuse of the wife of the starosta of Žemaitija Zofia Chodkevičienè, who apologized for having delayed the musician for a long time. Thus, professional musicians were valued and lent to other courts. ${ }^{61}$

(4) The Female Quarters: Ladies, Maids and Servants The female quarters were hierarchically structured only in the noblewomen's courts. In the sources they are referred to as 'female attendants, fraucymer, fralchumierky, dziewki and maids' Women were in the minority even in the noblewomen's courts. In the sixteenth century women made up only 20 per cent of all the courtiers in France. The male service was considered more prestigious for the court. ${ }^{62}$ The tradition to have female quarters in the court had existed since the start of the sixteenth century. After the death of Z. Goštautienè, the wife of Vilnius palatine, in 1549 her girls were not left to their own devices. ${ }^{63}$

Several hierarchical groups can be distinguished in the female quarters of noblewomen's courts: ladies, followed by maids and servants, workers and unfree girls occupying the lowest position. In many respects the court was a motley group of women. The list of Kločkienè's courtiers shows that their social status varied tremendously: some were noble, while others were virtually slaves. The servants of the noblewoman were probably on the list of the female courtiers. The age and marital status were important as well. Married, widowed and senior 'ladies' stood on a higher hierarchical step compared to a numerous flock of young still unmarried ladies, somewhat looked after by the older 'ladies'. They performed a task similar to that of the matrons in the court of the sovereign's wife. The woman's court was managed by a senior lady. As a rule, that

${ }^{61}$ Bychowiec to Tęczyńska, Skirmontowo, early 1582, AR, dz. V, nr. 1759; Z. Chodkevičienè to E. Sapiegienè, Vilnius, 2 Sept. 1602, AR, dz. V, nr. 2067.

${ }^{62}$ Kettering, 'The Household Service', p. 50.

${ }^{63}$ Sigismund August to Radvila the Red, Cracow, 13 Dec. 1549, Listy króla Zygmunta Augusta do Radziwiltów, ed. I. Kaniewska (Cracow, 1999), p. 139. 
was an elderly courtier in good standing with the noblewoman. In Kločkiené's court it was 'the old lady Vasilevskaia', in E. Ostrogiškaitè's court 'the old lady Elžbieta'64 (in 1597), and in Tęczyńska's court the Trakai housekeeper Zofija Triznienè. Ona, the wife of the court treasurer S. Mochaila, also belonged to Kločkienè's ladies.

To become a lady-in-waiting in a noblewoman's court was no easy task. One needed intercession, previous long-term service of the woman herself or her husbands, etc. Disagreement with the nobleman or his wife complicated chances of moving to some other court. Thus, lady Hzanovska, not getting along with Radvila the Orphan's family, got into difficulties while finding a place in some other court. ${ }^{65}$

Being nearest to the noblewoman, the ladies-in-waiting accompanied their patroness on her journeys and kept her company. Isolated notes furnish some information on the names or evidence of the activity of some courtiers. Female courtiers communicated with the courtiers of their patroness's husband. Thus, in 1597 the Radvila servant Piuro forgot to whom the courtier of the nobleman's wife lady Wirszikowska asked him to hand over presents. It is not clear why Radvila the Orphan rushed lady Skarzewska from Nesvizh to Minsk in 1603. The female courtiers had many opportunities to prove their allegiance, in particular in cases of discord between the noble spouses or the parents and their children. Radvila the Thunderbolt spoke about ladies Pesliakova and Čekanovskis' wife, from whom his wife did not hide anything. ${ }^{66}$ The courtier lady Ivanova Bogushe-vichova possibly knew many of Tęczyńska's secrets. The noblewoman being at odds with her grown-up sons, even her courtiers faced mortal danger. Bychowiec more than once wrote to his patroness about a bad behaviour of the dukes Sluckis towards her courtiers and servants. Having found out about Bogushevichova's trip to Turcz, Jurgis Sluckis sought to detain her. For fear of being shot, she had to return back. It is known that in 1581 a servant of

${ }^{64}$ Radvila the Thunderbolt to his servants, Bielica, Nov. 1596, Vilnius, 30 Dec. 1596, AR, dz. IV, kop. 291.

${ }^{65}$ Z. Olekaitienè to Radvila the Orphan, Sialets, 1 Aug. 1590, AR, dz. V, nr. 14636.

${ }^{66}$ Radvila to Orechovinskis, Sialets, 20 Oct. 1596; Radvila the Thunderbolt to Baltromejavičius, Vilnius, 18 Jan. 1597, AR, dz. IV, kop. 291; E. Sapiegienè to Radvila the Orphan, Lososina, 26 Sept. 1603, AR, dz. V, nr. 13893. 
Tęczyńska's was lady Prozova. In 1588 the noblewoman borrowed as many as $600 \mathrm{zl}$. from the courtier Kotryna Hansulova. In 1598 the duchess Sokolinska, ladies Kunovska and Stanska kept company with the noblewoman. ${ }^{67}$

Table 3: Kločkienès Courtiers in 1552

\begin{tabular}{|c|c|c|c|}
\hline Courtier & Social status & $\begin{array}{l}\text { Years of } \\
\text { service }\end{array}$ & $\begin{array}{l}\text { Reward } \\
\text { (in groats) }\end{array}$ \\
\hline 1. Lady Vasilevskaia & $\begin{array}{l}\text { gentry woman } \\
\text { gentry woman }\end{array}$ & 3 & $\begin{array}{c}\text { a coat lined with } \\
\text { fox fur, a dress, } \\
240\end{array}$ \\
\hline $\begin{array}{l}\text { 2. Uršulè Zbrožkovna, } \\
\text { relative of the diseased }\end{array}$ & gentry woman & 4 & $\begin{array}{c}\text { damask for } 300 \\
\text { and } 900\end{array}$ \\
\hline 3. maiden Chodakovska & gentry woman & 6 & 600 \\
\hline 4. Hana Mochailovaia & landlady & 3 & 900 \\
\hline 5. Dorotka & gentry woman & 8 & 600 \\
\hline 6. Marina, housekeeper & unfree & 15 & 300 \\
\hline 7. Alena Izaeva & unfree & 12 & 300 \\
\hline 8. Chrystyna & unfree & 15 & 240 \\
\hline
\end{tabular}

Young ladies were a separate group in the female quarters. The schooling of young gentlemen at the courts of the GDL nobility in the sixteenth century has been discussed by historians quite intensively, while the education of girls in noblewomen's courts has been ignored. Actually the parallel was obvious: the noblemen's courts were considered a suitable place for the training of young men, and many girls were educated in the noblewomen's courts. Usually orphaned relatives were taken into the courts - that was considered a duty, a point of honour, and also a way of recruiting allies ${ }^{68}$ - rich gentry families and clients used to send their daughters to noblewomen's courts. In 1582-1583 Tęczyńska tutored a considerable number of girls, who, according to an official, 'are healthy and properly kept', 'through your kind offices they have what to drink and to eat'. The official distinguished a daughter of Kristina Zborowska and the Vilnius castellan Jonas Chodkevičius (d. 1579) - the patroness seemed to have taken better care of her than her natural mother. In 1582 the official wrote that the castellan's daughter had eyesight

${ }^{67}$ Bychowiec to Tęczyńska, Skirmontowo , 4 March 1583, AR, dz. V, nr. 1759; Triznienè to Tęczyńska, Ostashino, 22 Feb. [1581], AR, dz. V, nr. 16475; AR, dz. XI, nr. 28; Varena, 8 Nov. 1598, BN, mf. 21251.

${ }^{68}$ Kettering, 'The Household Service', p. 50. 
trouble and in the autumn of 1583 she lacked clothes, and 'Her Worship lady mother is totally unconcerned with her. She has been living in Shklov since her departure there in autumn'. ${ }^{69}$

After resettling their daughter, the parents (or patrons) had to provide her well according to her status. The noblewomen as often as not profited by the occasion. Kotryna Hlebavičiene, wife of the Trakai palatine reared Kotryna Raiska. In 1593 her husband Kasparas Šveikovskis and she went to law, arguing that her patroness and her deceased husband Jonas Hlebovičius owed her $6.000 \mathrm{zl}$. as her dowry. That sum was bequeathed to her by her father, the royal marshal Steponas Raiskis, who had left 120,000 groats to her dead brother Adomas and 24,000 to her in his will. All in all, the patroness had paid her 30,900 groats. ${ }^{70}$ Consequently, it was worth to foster rich young ladies at the court.

The system of rewarding the maidens is not quite clear. In squaring the accounts with Kločkiene's courtiers, the relative Uršule Zbrožkovna, having served four years, was rewarded with as many as 900 groats and a valuable cloth. In this particular case the girl's social position could be taken into consideration. Tęczyńska could hardly have paid the daughter of Vilnius castellan, especially since she had to look after her too.

Young ladies' life at the court was influenced by the decision of their patrons. Quite a number of them left K. Sluckiene's court or were taken from there in 1582 in the aftermath of the noblewoman's quarrel with her sons. Early in the year ladies Dorovska, Bohdanova, Volodkievičova and Osmolska removed their daughters from the court. A certain Falkovskis and his wife, servants of the noblewoman's son duke Semionas Sluckis, talked the noble courtiers Carnoslavska and Lazovska into going over to Sluckis' court. On the duke's orders they were taken from Turcz. Attempts were made to coax lady Rosčanka as well, since it was known 'what wealth the lady mother had brought'; therefore she was taken to the noblewoman's safe Vsialub court without delay. ${ }^{71}$ It can only be guessed what made Povilas Ivanovičius Sapiega to take his niece Ona Michailovna Sapiegaite from 'the care and protection' of the wife of Vilnius palatine Ona Zeslavska Hlebavičienė and send her to the court of the wife of Radvila the Black. Here she was 'respectably looked

${ }^{69}$ Bychowiec to Tęczyńska, Skirmontowo, 4 March 1583, AR, dz. V, nr. 1759.

${ }^{70}$ LMAB, f. 16, Nr. 53, ff. 22, 24.

${ }^{71}$ Bychowiec to Tęczyńska, Skirmontowo, early in 1582, 14 Oct. 1583, AR, dz. V, nr. 1759. 
after and well catered for according to her status of a young lady' by her uncle. Subsequently from here she was married to the Zhitomir starosta Duke Andrius Pronskis 'by her own volition'. Afterwards the niece amply repaid her uncle by transferring to him the land domains of Panemunè and Gedgaudiškiai, which she had received from Fridrichas Ivanovičius Sapiega. ${ }^{72}$

Maidservants and various other specialized female workers belonged to the female court. Kločkienè's list of courtiers comprised three maids - Marina, Aliona Izaeva and Chrystyna - side by side with the gentry courtiers. Their low origins and lack of freedom makes one surmise that they were merely servants, or as in Marina's case, sort of housekeepers. Maidservants and unfree girls were often mentioned in the noblewomen's wills. In 1555 O. Korickienè reminded her husband: 'give the handmaids and unfree maidens freedom and let them be married to free men ... so that they would not be my soul's burden'. ${ }^{73}$

Judging from the list of Barbora Radvilaite's maidservants, peasant women could hardly have had access to the royal apartments. ${ }^{74}$ Noblewomen were attended mostly by gentry women, only possibly from the lower layers. A vivid example of this situation is a tragic case of Jadviga Matiiasovna, a maidservant of Ona Podsentkovna, wife of the royal ostler Jonas Rajeckis. The maid was 'of lowly origins, a peasant', a daughter of Rajeckis' subjects Vaitiekus Kèkštas and a relative of Jonas Sirgintas. In 1598 in the Rajeckis' Panemunè court there was a party, at which many well-known Lithuanian nobles were present. Among the guests there were Jonas and Mikalojus Buivydas, the nephews of the landlord Simonas Vainilavičius. Being drunk, the Buivydases pushed their way into the room which was then occupied by the lady Rajeckis and the GDL steward Stanislovas Diatkovskis. The lady, being unable to hold the door, called her maidservant (devka sluzhebnaia) Matiiasovna to her assistance. Mikalojus Buivydas shot at the maid and she died. Rajeckis, not even countenancing the possibility that his wife's servant could have been a peasant, filed suit against Buivydas. And it was then that the maid's origin came to light. The ostler continued legal proceedings against the

${ }^{72}$ LMAB, f. 16, Nr. 202, f. 236.

${ }^{73}$ LM, Nr. 43, f. 21.

${ }^{74}$ Marchwińska, 'Rejestr dworu', pp. 101-102. 
killer, so that 'that innocent blood, spilt in his home, would not be left unpunished ... and would not incur the wrath of God'. At a glance that would look like a praiseworthy humane behaviour of the official. However, this illusion disappears on getting acquainted with the defender's speech in which he stated that those legal proceedings were redundant because the deceased was a commoner, and, what was most important, she died 'not of the bullet', but because of Rajeckis' greed - he prevented the medical attendant from examining the wound..$^{75}$ This sad incident shows that there were peasant women among the maidservants.

In the female quarters a relatively low position was occupied by various handmaids: washerwomen, housemaids and other servants. They were supervised by a female courtier or some other person appointed by the noblewoman. In the summer of 1583 Tęczyńska's handmaids were controlled by a certain pan Račkas. Due to the noblewoman's quarrels with her sons even the lowest personnel fled the court. According to Trizniene, 'even Zoska, your Worship's best maid, has disappeared from Turcz nobody knows where'. Nevertheless, the handmaids differed from unfree girls. These two categories were dealt with separately in the aforementioned Korickiene's will. There could be dependant female peasants among the handmaids, while the unfree girls were completely subjected to the noblewoman. As a result of the Livonian War the number of Muscovite unfree girls increased in the latter half of the sixteenth century. It is noteworthy that they were in demand. For example, in 1581 the wife of the starosta of Žemaitija and the Duchess Sluckienè talked about two Muscovite captives, they were satisfied with them and desired to have more of them. ${ }^{76}$

Service in a noblewoman's court was a worthwhile job even for a captive. Their patronesses, though often for religious motives, asked their relatives to release them and marry them off into appropriate families. The captives were properly rewarded by Kločkienè.

Thus, the servants even in the lowest positions could expect certain prospects: freedom, salary and successful marriage.

(5) Court Service The 1552 list reveals the category of craftsmen at the noblewoman's court. It comprised a goldsmith, leather-

${ }^{75}$ Kaunas Land Court Book, 1600-1601, VUB RS, f. 7, nr. 33, ff. 1061-1062.

${ }^{76}$ Triznienè to Tęczyńska Radvilienè and Radvila the Thunderbolt, Ostashino, Feb. 1581, 8 June 1583, AR, dz. V, nr. 16475. 
worker, a shoemaker, an artist, some cooks and a butler. This list is far from exhaustive - the noblewomen could hardly dispense with the services of such people as dressmakers or seamstresses. Besides, some craftsmen were mentioned without indicating their speciality. Some other sources indicated more varied professions. The Duchess Sluckienè had a seamstress, who used much silk and gold thread in her work. This courtier, as well as the goldsmith, performed the noblewoman's commissions. The unnamed goldsmith must have been highly qualified and, possibly literate, since through a court official he sent his patroness his work with a letter attached to. ${ }^{77}$

In the service of the noblewoman's court quite a number of people were associated with the kitchen. No less than three cooks served for Kločkienė; closely related with this service was the butler. Incidentally, people, connected with the kitchen, were the longest serving at the court. Thus, one of them, Stanislovas Šimka, worked for over twelve years. That shows that they took a positive attitude to their service at the court as a permanent place of work. On the other hand, there were cooks who were constantly looking for better patronesses. In the spring of 1582 a certain cook called Levonas, possibly formerly invited by Sluckiene, informed her that 'he did not work any more for his Vilnius lady' and he could be of service to a new patroness and enquired where he could see the duchess. ${ }^{78}$ The noblewoman also employed officials, recommended by other persons. Thus, in 1588 the palatine of Vilnius, Radvila, sent his wife a good cook. Having tasted the mouth-watering bread, the noblewoman sent the baker to her husband in Simiatichi - 'you'll see you have never tasted more delicious bread'. ${ }^{79}$

Only qualified craftsmen could be given jobs in domestic service at the courts. Noblewomen seem to have promoted their skills to a certain extent. The wife of the chancellor of the Grand Duchy, Sapiega, wrote to her brother rather categorically on this issue in her letter in 1606 - she indicated that she could not send a certain craftsman earlier, only after the holidays and requested that 'that apprentice be taught $\ldots$ and not be wilful'. ${ }^{80}$

${ }^{77}$ Bychowiec to Tęczyńska, Skirmontowo, 4 March 1583, AR, dz. V, nr. 1759.

${ }^{78}$ Bychowiec to Tęczyńska, Slutsk, 15 May 1582, AR, dz. V, nr. 1759.

${ }^{79}$ Tęczyńska Radvilienè to her husband, Turcz, BN, mf. 4338.

${ }^{80}$ Radvilaitė-Sapiegiene to her brother Kristupas Radvila, Warsaw, 5 May 1606, AR, dz. V, nr. 13893. 
Table 4: K. Kločkiene's Court Service (Craftsmen) in 1552

\begin{tabular}{|l|c|c|}
\hline \multicolumn{1}{|c|}{ Craftsman } & $\begin{array}{c}\text { Years of } \\
\text { service }\end{array}$ & $\begin{array}{c}\text { Reward } \\
\text { (in groats) }\end{array}$ \\
\hline 1. Jacka, goldsmith & - & 60 \\
2. Krikar, currier, saddler & 2 & 120 \\
3. Andrius Michnovičius, & & \\
shoemaker & - & 60 \\
4. Mikalojus, painter (artist) & - & 60 \\
5. Stanislovas Šimka, cook & 12 & 120 \\
6. Michalka, cook & - & 60 \\
7. Stasas Jankovičius & - & 60 \\
8. Vaitieška, cook & - & 60 \\
9. Chuška, butler & - & 60 \\
10. Stanislovas Dubrovskis & - & 30 \\
\hline
\end{tabular}

In a way endorsing the statement of the sixteenth-century GDL humanist Andrius Volanas that 'it is very typical of our women that they do not stay at home, but pay visits to one another reaching all the corners of the city', ${ }^{81}$ Kločkienè mentions as many as three coachmen among her courtiers, who were salaried like the craftsmen. Stanislovas was given 120 groats, and Ostapka Prokuda and Andrius Čabanas 60 gr. each. Coachmen and other services linked to coaches and horses were very important in the noblewoman's life, they attested to her everyday activities. Even husbands' wills contain references to their wives' coaching: the GDL cuisinier Vaitiekus Jasenskis did not fail to indicate 'four coachmen and the carriage used by my wife ...? ${ }^{82}$

The upkeep of a great number of courtiers required large sums on the part of the noblewoman. In 1552 it took Kločkienè 15,570 gr. to settle scores with all her courtiers. Besides, she had to allot money for sick courtiers and for the repayment of borrowed money. However, these investments, although not yielding any palpable income, in actual fact were beneficial. First and foremost, the court was a very important indicator of the noblewoman's position in

${ }^{81}$ A. Volanas, Rinktiniai raštai, ed. M. Ročka and I. Lukšaitè (Vilnius, 1996), p. 167.

${ }^{82}$ LMAB, f. 43, Nr. 26624. 
society and a matter of her prestige. The importance of the court and the courtiers was apparent in her everyday life.

In this respect several episodes of the duchess Sluckiene's life in $1580-81$ can be informative. In the summer of 1580 various Lithuanian and Polish noblemen with large retinues visited the duchess's court in Slutsk. The palace was filled to capacity so that the duchess could not receive even the Trakai castellan K. Radvila who was courting her. The duchess was visited by the wife of the castellan of Vilnius and Lublin Madam Mikalojienė Zbarovska with nearly all her young ladies; they were joined by the wife of the Minsk judge. The Volhynia starosta with his spouse and children was present, too, as well as the Rogachev elder. The landlords, neighbours of the duchess, with their wives were there 'often and in great numbers'. Guests were frequent in other courts of the duchess - in Turcz and Ostashino often and at all times of the year. In May 1581 the wives of the Vilnius castellan and of the Žemaitian starosta, the duke Pronskis and many others from Nowogrudok had come to Turcz. On Shrove Tuesday the Cracow palatine, Mr. Piecki, the wife of the Šidlov starosta Madam Zborowska were expected in Turcz. The wife of the Žemaitian starosta joined those guests later, and so on and so forth. ${ }^{83}$ The guests were accompanied by several to a score of their own courtiers. The noblewoman herself met them with her courtiers and the guests were attended to by the people of the court.

To sum up, the overall picture would look something like this. The sixteenth-century noblewoman simply could not live a different life, the style of which was obligatory for the period, conditioned by the spirit of the Renaissance. The data about separate small courts of the noblewomen's daughters go back to the latter half of the sixteenth century. The noblewoman's role in appointing the courtiers to take care of their daughters was decisive. The largest courts, consisting of 50-60 persons, were those of married and, in particular, of widowed noblewomen. They were structured on the model of the court of the ruler's wife: consisting of several parts (the male and female quarters, the specialists and the court service) they functioned as a unit. In many cases it was the noblewomen who had the upper hand in appointing courtiers even when there were disagreements between the spouses or the children. In this way courts

${ }^{83}$ A. Trizna to Radvila the Thunderbolt, Slutsk, 4 July 1580, AR, dz. V, nr. 16463; Trizniene to Radvila the Thunderbolt, Ostashino, Jan., 3 May 1581, AR, dz. V, nr. 16475. 
enabled noblewomen to develop their own clientele system and on that basis to participate in public life and to create their home clientele. Through their mediation their clients could become clients of their husbands or other nobles. The court was a useful place for courtiers. Even the servants and workers at the bottom of the social ladder could expect to make some sort of career for themselves or ultimately obtain their freedom.

Translation: Alfonsas Laučka

\section{Author Details}

Dr. Raimonda Ragauskiene is a member of the Department of Palaeography of the Lithuanian Institute of History. Her research interests are in the Lithuanian Metrica (its study and publication) and the social history of the 16th-century Grand Duchy of Lithuania. She has published five monographs (two of them in co-authorship) and a number of articles on the Lithuanian nobility and gentry.

Address: Archeografijos skyrius, Lietuvos istorijos institutas, Kražių 5, LT-01108 Vilnius, Lithuania

Email: ragauskiene@istorija.lt

\section{A. LIETUVOS DIDŽIOSIOS KUNIGAIKŠTYSTĖS DIDIKĖS DVARAS}

\section{Santrauka}

\section{RAIMONDA RAGAUSKIENE}

Straipsnyje, remiantis išlikusiu 1552 m. Žemaitijos seniūnienès dvariškių sąrašu, paminejjimais korespondencijoje, pomirtiniais turto inventoriais ir pavieniais aktais, bandoma atkurti apibendrintą XVI a. LDK didikès dvaro sudèti, jo dalis, dvariškiu atliekamas funkcijas. Kartu mėginama ivvertinti, kokị vaidmeni formuojant dvara, skiriant pareigūnus, kooptuojant dvariškius atliko pati didikè, kur prasidèjo ir baigèsi jos kompetencija, koks buvo patronatas didikès dvaro rèmuose.

Dvaro dydis priklausė nuo moters padėties visuomenèje: vyro užimamų pareigų, moters atliekamo vaidmens šeimoje ir didikès asmenybès. Nepilnametei patarnavo vos keli asmenys, gausiausi - apie 50-60 asmenų - buvo ištekejjusių, o ypač našliu dvarai. Didikès dvarą paprastai sudarè kelios dalys, veikiančios kaip viena visuma: dvaro pareigūnai, vyrų dalis dvare (dvariškiai vyrai ir pasiuntiniai), specialistai dvare (medikai, dvasininkai ir muzikai), moterų dalis (ponios, panelès, tarnaitès) ir dvaro tarnyba (tarnai, amatininkai, vežikai). Ištekejjusios didikès dvaro formavimui didžiausią įtaką turèjo vyrai. Pati didikè naujai pertvarkydavo savo dvarą likusi našle.

Gausaus dvariškių būrio išlaikymui reikèjo nemažų didikès investicijų, kurios, nors ir neduodavę matomo pelno, iš tiesų labai apsimokëjo. Dvaras pirmiausia buvo svarbus didikès socialinei pozicijai visuomenejje patvirtinti, jos prestižo reikalas. Per jị didikè turejjo galimybę plètoti savo klientelinę sistemą ir aktyviai dalyvauti viešajame gyvenime, kurti savo namų klientelą. Dvariškius pastebejjus vyrui ar to paties luomo bičiuliui, didikei užtarus, jos klientai tapdavo jų klientais. 